\title{
Salmonella Serotype Paratyphi B
}

National Cancer Institute

\section{Source}

National Cancer Institute. Salmonella Serotype Paratyphi B. NCI Thesaurus. Code C86924.

Any bacterial organism that can be assigned to the genus Salmonella with serotype Paratyphi B. 